\title{
Evaluation of Dust Elements on Photovoltaic Module Performance: an Experimental Study
}

\author{
Hussein A. Kazem ${ }^{1,2}$, Miqdam T. Chaichan ${ }^{3}$ (D), Ali H.A. Al-Waeli ${ }^{2,}$, Kamaruzzaman Sopian ${ }^{2}$ (D), \\ and Abdul Salam K. Darwish ${ }^{4}$ (D) \\ ${ }^{1}$ Sohar University, PO Box 44, Sohar, PCI 311, Oman \\ 2 Solar Energy Research Institute, Universiti Kebangsaan Malaysia, 43600, Bangi, Selangor, Malaysia \\ ${ }^{3}$ Energy and Renewable Energies Technology Research Center, University of Technology, Iraq \\ ${ }^{4}$ University of Bolton, Bolton, UK
}

Received: 28 June 2021 / Received in final form: 29 July 2021 / Accepted: 29 July 2021

\begin{abstract}
Dust is a natural phenomenon, and it represents all the components suspended in the air. Dust causes the photovoltaic performance to deteriorate. The main dust components concentrations vary from one geographic location to another and from one season to another. These components also have different effects on the PV power losses. Therefore, studying the effect of the concentration of each dust component separately can give a greater clarification and detail of how the accumulated dust affects the behavior of the PV module. In this study, the dust accumulated on a photovoltaic cell was collected and analyzed into its basic components. The results showed that most of the dust of Sohar city consists mostly of sand (65\%) coming from the Empty Quarter desert adjacent to the Al-Batinah region. Also, volatile building materials such as cement and gypsum have high concentrations in this dust, which are $5.25 \%$ and $4.94 \%$, respectively. In addition, high concentrations of ash $4.92 \%$, which is resulting from burning fuels in smelters, power plants, and refineries. The effect of most of the studied dust components was limited on the current of the photovoltaic cell, but their effect was clearer on the cell voltage. As a result, the decrease in power generation was especially evident in the case of ash, cement, and new garment, but the biggest decrease was due to sand. While iron powder and red sand had the least effect on the performance of the photovoltaic cell.
\end{abstract}

\section{Introduction}

Solar energy can be considered the most reliable and most widespread renewable energy source for generating electricity around the world [1]. Photovoltaic systems that produce electricity directly from sunlight can be considered one of the most important applications of solar energy. Photovoltaic modules are one of the rapidly developing business sectors, as the annual growth rate of installed and in-service photovoltaic installations reached $40 \%$ from 2010 to 2016 [2]. Photovoltaic cells are characterized by a long operational life of 20 to 25 years, and the time to recover the cost of construction and operation is no more than 7 operational years. It is also characterized by the flexibility of its installation in mountains, valleys, plains, and even seas [3].

Since the photovoltaic cells are installed externally facing the sun and away from the shade, so they are affected

\footnotetext{
* e-mail: ali9alwaeli@gmail.com
}

by external weather factors [4]. Various factors can affect the efficiency of solar panel systems by either increasing or decreasing energy production such as the solar radiation intensity, cloud cover, relative humidity, heat build-up, and dust [5-8]. Practically, solar panels must be installed in areas free from shades because any shading, even on a small part of the panel, can have a significant impact on the energy produced [9]. Dust accumulated on photovoltaic units is an important factor in reducing their productivity. Sadly, the best areas in the world in terms of the high solar intensity are concentrated in deserts and have a high density of dust in their atmosphere [10]. The decrease in the productivity of solar cells depends not only on the amount of accumulated dust but also on the components of this dust and their physical and chemical properties [11-14]. The physical and chemical properties of dust differ from one region to another. These properties depend mainly on the source of the dust [15]. In desert areas, the dust originates from the soil, but in industrial cities, for example, there are many sources of dust, such as the exhaust of automobiles, equipment, and trucks, and 
chimneys of electricity production plants, in addition to various volatile building materials from construction sites $[1,16]$.

The accumulation of dust on the photovoltaic modules increases as the slope of these modules decreases. Ghazi et al. (2014) showed that installing the cell in the horizontal position is the worst degree of inclination for PV modules, which causes the largest accumulation of dust. Note that installing solar cells in a horizontal position is most appropriate in areas north of the equator (such as Oman) [17].

Several published studies examined the negative impact of dust accumulation on PV cell productivity and how to reduce these effects. In brief, we will go through some studies in this regard in the Sultanate of Oman and its neighboring countries. Reference [18] investigated the effect of leaving PV cells uncleaned for 45 days exposed to external conditions. This caused the production capacity to decrease by up to $50 \%$ after 45 days. The researchers found that cleaning the photovoltaic modules with water mixed with ionic and cationic materials caused the cell to restore its initial efficiency. Reference [19] surveyed the area of Oman and found that only $9 \%$ of Oman can be considered suitable for the installation of photovoltaic systems. Because these areas have moderate temperatures with a clear decrease in the concentrations of dust and mineral pollutants in their atmosphere. Reference [20] showed that the quality of the accumulated dust and the level of this accumulation are directly related to the resulting deterioration in the efficiency of the photovoltaic unit. The researcher also analyzed the dust accumulated on the cells; it was found that this dust was consisting mostly of (sand, calcium carbonate, silica, red soil, and ash). Among these components, the accumulated ash caused the highest deterioration in cell productivity.

In Saudi Arabia, reference [21] found that increasing the angle of inclination of the cell reduces the amount of accumulated dust. Reference [22] also showed that the photovoltaic units installed in the eastern part of Saudi Arabia (near the Arabian Gulf) lose about $50 \%$ of their efficiency if they remain for six months without cleaning. Reference [23] found a decrease in light transmittance by up to $84 \%$ due to dust accumulation on photovoltaic units in Saudi Arabia. The study concluded that a large part of this loss can be restored by washing and wiping the cells.

Reference [24] studied the effect of dust accumulation on photovoltaic units for a year without cleaning in the United Arab Emirates, the northern neighbor of the Sultanate of Oman. The study concluded that polycrystalline panels have the best cleaning factor. While reference [25] showed that the accumulation of dust on the surfaces of solar panels reduces the transmittance of glass by up to $10 \%$ and its electrical efficiency by up to $70 \%$ in the United Arab Emirates.

In Qatar, reference [26] investigated the effect of the size of the accumulated dust particles on the photovoltaic modules installed in Qatar and the effect of exposure time on these sites. The results showed that the accumulation of particles of small sizes caused a greater decrease in the efficiency of cells compared to particles of large sizes. As for reference [27] has studied the effect of dust accumulated with high relative humidity on the resulting losses in the efficiency of photovoltaic units. After observing and checking the intensity of solar radiation, accumulated dust, and the rest of meteorological data for 12 months in a desert area in Qatar. In Qatar, too, reference [28] evaluated the effect of the accumulated dust on the photovoltaic units installed in the city of Doha after they were left for ten months without cleaning with continuous monitoring of the rate of dust accumulation and changes in the cleanliness index. The study concluded that the accumulated dust particle size and concentration decreased with increasing exposure time. Reference [29] also showed that the accumulation of dust increases on the surface of the solar panels if the wind speed is less than $3 \mathrm{~m} / \mathrm{s}$. Reference [30] demonstrated that the formation of dew on the surfaces of PV modules enhances the adhesion of dust particles accumulated on these surfaces depending on the chemical components of the dust.

Reference [31] emphasized that photovoltaic technologies offer a promising and competitive alternative and can positively affect the economy of the desert and rural areas of Yemen (Oman's neighbor).

In a review study of dust conditions in Iraq, reference [32] that the fertile Mesopotamia, after 20 years of continuous drought, turned into a basin source of dust and sand storms for the area surrounding this country. A large number of dusty days in the airspace of Iraq is the main obstacle in not focusing on this technology and paying attention to it, despite the country suffering from a stifling electricity crisis. Also in Iraq, reference [33] studied the effect of dust accumulation on PV modules installed near a highway in the Iraqi capital, Baghdad. The results showed a decrease of about $12 \%$ after the organization worked for two months without cleaning. The researchers focused on the fact that cleaning the photovoltaic unit with a sodium solution causes a greater recovery of the produced power than if it was cleaned in water or rain.

In Iran, reference [34] studied the effect of dust accumulated on photovoltaic modules that were exposed to atmospheric conditions for 70 days continuously and without rain. The accumulation of dust naturally on the surface of the tested PV module during this period reached $6.0986 \mathrm{~g} / \mathrm{m}^{2}$. The output losses reached $21.47 \%$, which equates to a loss of $289 \mathrm{kWh}$ per cycle of $4845 \mathrm{~kW}$ due to this accumulation of dust. In Turkey, reference [35] studied the effect of coal dust accumulation (of varying sizes and weights) on the output losses of PV modules. Experiments were carried out under standard conditions using two types of PV modules (monocrystalline (m-Si) and polycrystalline (p-Si)). Several blocks of charcoal dust (5 g, $10 \mathrm{~g}, 15 \mathrm{~g})$ were also used. Coal dust accumulation caused output losses of maximum $60 \%$ and $62 \%$ for both monocrystalline and polycrystalline modules, respectively.

Reference [36] examined the losses due to dust accumulation on the productivity of PV modules in Egypt. The authors used two types of photovoltaic panels (monocrystalline and polycrystalline). The accumulated dust caused an output loss of $30 \%$ of the PV modules' yield. It was also shown that the module's tilt angle affects its efficiency. The study concluded that the best tilt angles are $15^{\circ}$ and $30^{\circ}$ for $\mathrm{PV}$ modules, which gave the greatest 


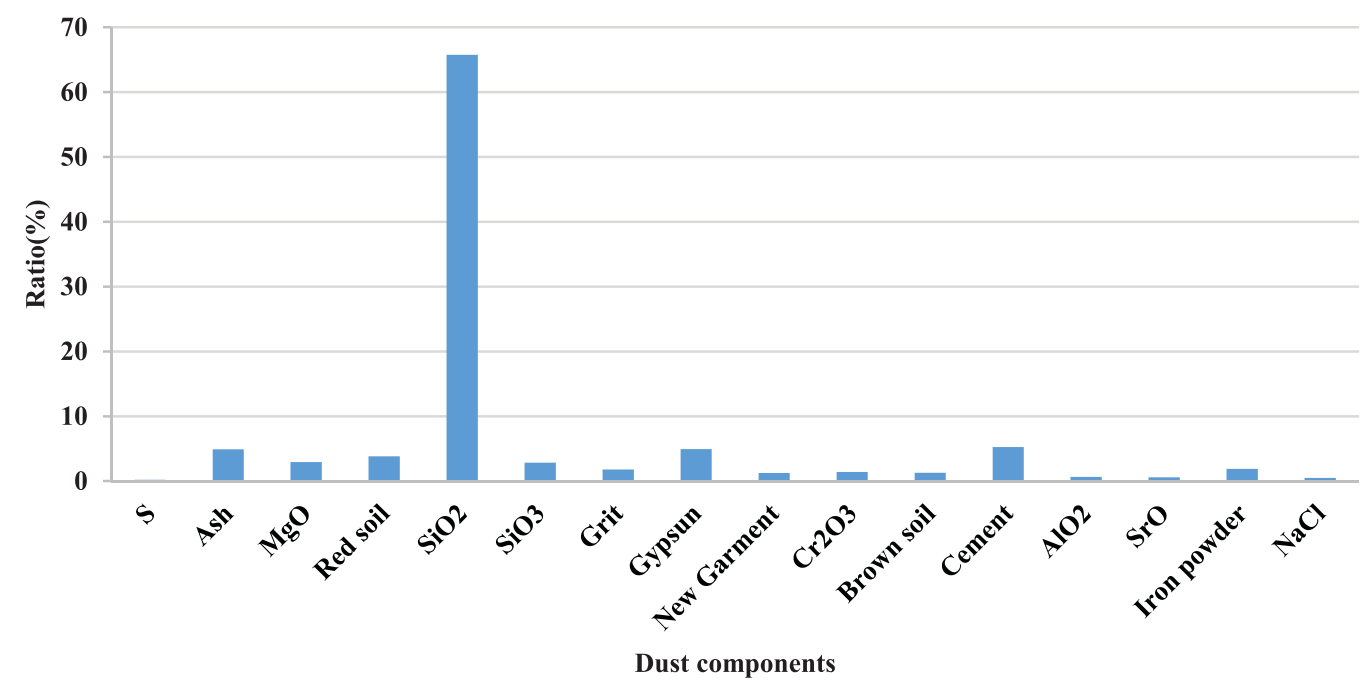

Fig. 1. Sohar city dust composition.

productivity. In Pakistan, reference [37] studied the effect of dust accumulation on two types of PV modules (monocrystalline and polycrystalline). The studied modules were exposed to external conditions for a whole month. The productivity of mono-PV and polycrystalline modules decreased by $16.16 \%$ and $11.54 \%$, respectively. The cleaning process of both types of PV modules restores $98 \%$ of their efficiency.

After this brief introduction, it is clear that the concentrations of dust components differ from one season to another and from one region to another. Therefore, examining the effect of the concentration of each of the dust components separately can give a greater clarification and detail of how the accumulated dust affects the behavior of the photovoltaic module.

\section{Studied area}

Sohar is the administrative center of the North Al Batinah Governorate and is located in the north of Oman. Sohar is about $234 \mathrm{~km}$ from Muscat and was previously dependent on agriculture, trade, and fishing. Currently, Sohar is the hub of the Omani industry. The city has an industrial port. Sohar overlooks the Sea of Oman with a $45 \mathrm{~km}$ coastal strip. It is also located in a plain area with a distance of ten kilometers and then in a mountainous area. This topographical diversity and the presence of a large desert bordering the mountains to the west made Sohar exposed to dust storms. Its weather is mostly warm in winter and hot in summer with a clear decrease in rainfall and high relative humidity most days of the year [38].

The city of Sohar has witnessed drastic economic and investment transformations and has achieved a number of giant investment and economic projects. Sohar has entered the stage of heavy industries and the establishment of the Sohar Industrial Port has facilitated investment in heavy industries such as the Sohar oil refinery, aluminum factory, Oman propylene factory, petrochemical complex, and other giant projects.

\section{Experimental setup}

To examine the effect of each of the components of the accumulated dust, a sample of the accumulated dust was taken for a month on the cell and examined using it to indicate its components. In the second step of the study, the focus was on finding each component separately by monitoring potential areas for export to the atmosphere and taking pure samples from them. The practical study of the effect of dust on PV systems was carried out using a system consisting of two monocrystalline silicon photovoltaic panels with dimensions of $1.43 \times 0.63 \times 0.9 \mathrm{~m}^{2}$, with a maximum power of 125 watts, an open-circuit voltage of 21.8 volts, and 7.45 amps of short-circuit current, and weighing $3.5 \mathrm{~kg}$. One of the two cells used was always kept clean, while the second was contaminated with different dust components in measured quantities for comparison purposes.

The following measuring devices were also used

A digital voltmeter for measuring voltage and current type "HAILANGNIAO" and has a measurement accuracy of $98.7 \%$.

- A meter for the intensity of solar radiation (range 0-1500 watts / square meter) manufactured by "WE300" and has a measurement accuracy of $98 \%$.

- Temperature sensor type "WE710" with an accuracy of $99.7 \%$.

- Sensors for air temperature and relative humidity type "RHT2nl-02" with a measurement accuracy of up to $98 \%$.

- Wind speed and direction gauge (with a measurement range of $0-30 \mathrm{~m} / \mathrm{s}$ and an accuracy of $97 \%$ ) type "MoreSunsDIY".

Because the study is practical, specific weights of the studied dust components were placed on the surface of the contaminated cell and shaken with a type-vibrator for half an hour to ensure that the pollutant spreads evenly on the surface of the solar cell, then left for half an hour to settle, after which the cell is fixed on its external holder and readings are taken. The process is repeated three times on three consecutive days at the same hours of the day to 


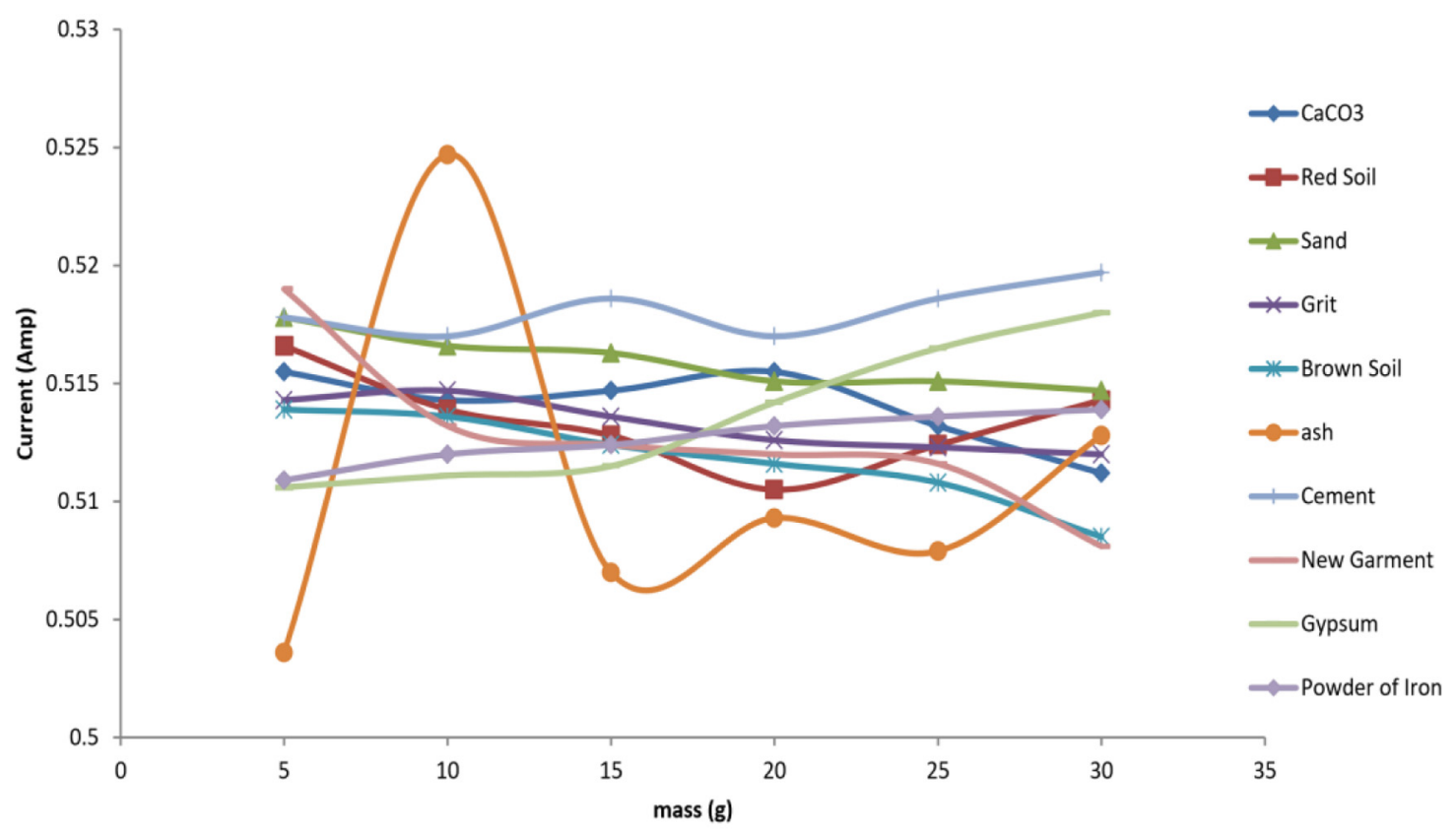

Fig. 2. Effect of changing the weight of the studied impurities accumulated on the current of PV cell.

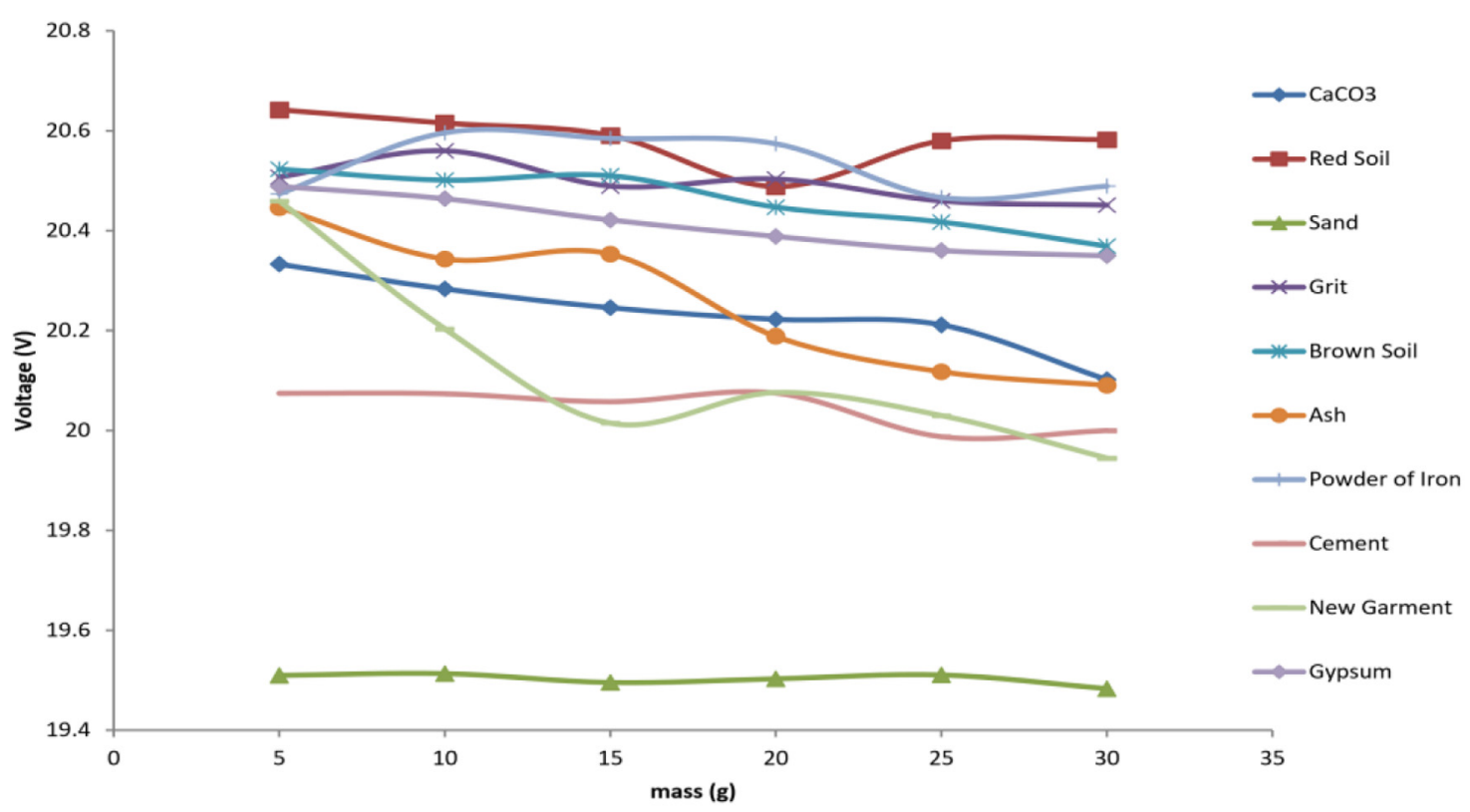

Fig. 3. Effect of changing the weight of the studied impurities accumulated on the voltage of PV cell.

ensure repeatability. Clean the cells in the evening. The study was conducted from March 31, 2018 to December 1, 2020 .

\section{Results and discussions}

Figure 1 shows the components of dust accumulated in Sohar as a percentage of the screened sample. It is noted that the bulk of the dust is silicon oxide coming from desert dust without impurities. It is very fine and dry dust, meaning that the adhesion to the surface of the photovoltaic cell is relatively weak. As for the highest concentrations, it is attributed to cement (5.25\%) and gypsum $(4.94 \%)$, both of which are construction materials used in construction operations, and their presence in these concentrations shows the severity of the current construction work in Sohar, while not being careful to prevent the volatilization of these materials in the atmosphere. Both materials represent a big problem if they are deposited on the surface of the photovoltaic cell in the presence of high humidity or water, as they form a highly adherent layer to 


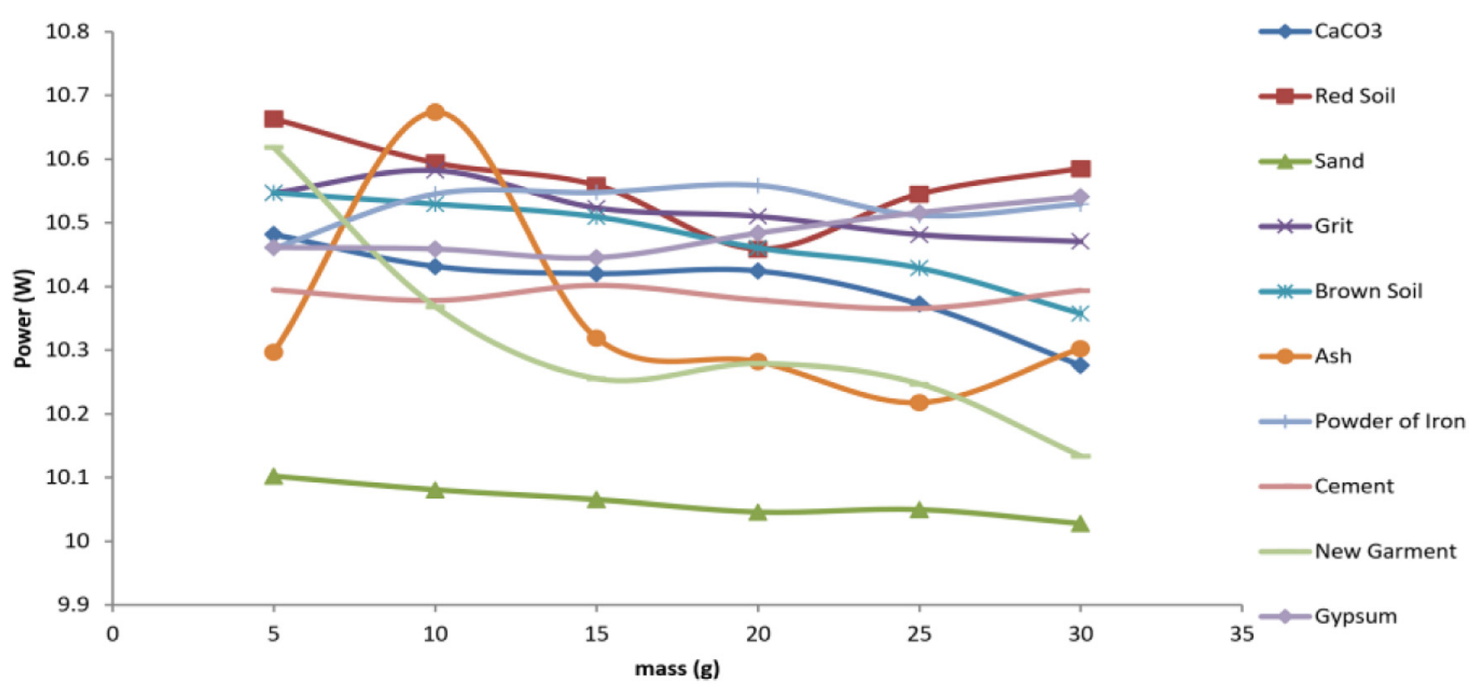

Fig. 4. Effect of changing the weight of the studied impurities accumulated on the voltage of PV cell.

the cell surface. The ash produced from smelter stacks, refineries, and power stations has a concentration of up to (4.92\%), which is considered high relative to the rest of the components. As for the rest of the ingredients, such as Grit (1.79\%), New Garment (1.26\%), brown soil (1.27\%), and iron powder $(1.88 \%)$.

Figure 2 shows the effect of accumulating upward weights from the studied components of Sohar dust on the resulting stream. The current is affected by the accumulated dust, as it prevents sunlight from reaching, reducing the movement of free electrons. It seems that the impact of the current is high in the case of the accumulation of brown soil and new garment. As for the rest of the components, the effect is almost very small, especially in the case of cement. Cement is made of small size particles and therefore, when evenly distributed on the surface of the cell, is spaced so as to allow the passage of sunlight. The impact of the current on the ash was changing from one weight to another, and in general, the effect of the ash was the largest on the current.

Figure 3 shows the change in the voltage generated in the PV cell with the change in the mass of the accumulated studied impurities. Sand seems to cause the greatest decrease in the generated voltage, in contrast to red sand and iron powder, which cause the least effect on the voltage. Cement and new garment cause an obvious drop in voltages. Sand particles are tiny and their distribution on the PV panel surface caused this voltage drop.

Figure 4 shows the change in the generated power in a PV cell with the change in the weight of the accumulated studied impurities. Sand causes the largest decrease in the generating power, unlike red sand, and iron powder, which caused the least decrease in the power by increasing their accumulated mass. Ash, cement and new garment caused a significant decrease in power. The results give a roadmap to determine the effect of all studied components on the generated power of the PV module and thus the possible reduction can be determined and how to reduce it by using optimum PV cleaners.

\section{Conclusions}

In this study, the dust in Sohar city accumulated on a PV was collected and analyzed. Examinations showed that the dust of Sohar consists mostly of silicon oxide coming from desert dust (65.76\%). Also, many components have high concentrations, such as cement (5.25\%), gypsum (4.94\%), ash $(4.92 \%)$, Grit (1.79\%), New Garment (1.26\%), brown soil $(1.27 \%)$, and iron powder $(1.88 \%)$. The results showed that the effect of most of these components is limited on the current of the photovoltaic cell, but their effect is clearer on the cell voltage. As a result, the decrease in power generation was especially evident in ash, cement, and new garments, but the biggest decrease was due to sand.

\section{References}

1. M.T. Chaichan, H.A. Kazem, Experimental evaluation of dust composition impact on photovoltaic performance in Iraq, Energy Sources A (2020) https://doi.org/10.1080/ 15567036.2020.1746444

2. H.M. Al-Maamary, H.A. Kazem, M.T. Chaichan, Changing the energy profile of the GCC States: a review, Int. J. Appl. Eng. Res. (IJAER) 11, 1980-1988 (2016)

3. W.E. Alnaser, N.W. Alnaser, The impact of the rise of using solar energy in GCC countries, in Renewable Energy and Sustainable Buildings (Springer, Cham, 2020), pp. 167-183

4. R. Ruther, L.R. do Nascimento, R.A. Campos, Performance assessment issues in utility-scale photovoltaics in warm and sunny climates, Renew. Energy Environ. Sustain. 2, 35 (2017)

5. A. Sayigh, Up-date: renewable energy and climate change, Renew. Energy Environ. Sustain 6, 13 (2021)

6. P. Ferrada, F. Araya, A. Marzo, E. Fuentealba, Performance analysis of photovoltaic systems of two different technologies in a coastal desert climate zone of Chile, Sol. Energy 114, 356-363 (2015)

7. M.T. Chaichan, H.A. Kazem, A.H. Al-Waeli, K. Sopian, The effect of dust components and contaminants on the performance of photovoltaic for the four regions in Iraq: a practical study, Renew. Energy Environ. Sustain. 5, 3 (2020) 
8. J. Tanesab, D. Parlevliet, J. Whale, T. Urmee, Seasonal effect of dust on the degradation of PV modules performance deployed in different climate areas, Renew. Energy 111, 105-115 (2017)

9. H.A. Kazem, M.T. Chaichan, A.H. Al-Waeli, K. Mani, Effect of shadows on the performance of solar photovoltaic, Mediterranean Green Build. Renew. Energy 379-385 (2017)

10. M.T. Chaichan, H.A. Kazem, Generating Electricity Using Photovoltaic Solar Plants in Iraq (Springer, 2018)

11. M. Saidan, A.G. Albaali, E. Alasis, J.K. Kaldellis, Experimental study on the effect of dust deposition on solar photovoltaic panels in desert environment, Renew. Energy 92, 499-505 (2016)

12. T. Sarver, A. Al-Qaraghuli, L.L. Kazmerski, A comprehensive review of the impact of dust on the use of solar energy: history, investigations, results, literature, and mitigation approaches, Renew. Sustain. Energy Rev. 22, 698-733 (2013)

13. H.A. Kazem, M.T. Chaichan, Experimental analysis of the effect of dust's physical properties on photovoltaic modules in Northern Oman, Sol. Energy 139, 68-80 (2016)

14. F. Fujiwara, R.J. Rebagliati, L. Dawidowski, D. Gómez, G. Polla, V. Pereyra, P. Smichowski, Spatial and chemical patterns of size fractionated road dust collected in a megacitiy, Atmos. Environ. 45, 1497-1505 (2011)

15. A. Gholami, A. Saboonchi, A.A. Alemrajabi, Experimental study of factors affecting dust accumulation and their effects on the transmission coefficient of glass for solar applications, Renew. Energy 112, 466-473 (2017)

16. H.A. Kazem, M.T. Chaichan, A.H. Al-Waeli, K. Sopian, A review of dust accumulation and cleaning methods for solar photovoltaic systems, J. Cleaner Prod. 276, 123187 (2020)

17. S. Ghazi, A. Sayigh, K. Ip, Dust effect on flat surfaces-a review paper, Renew. Sustain. Energy Rev. 33, 742-751 (2014)

18. H. Kazem, T. Khatib, K. Sopian, F. Buttinger, W. Elmenreich, A.S. Albusaidi, Effect of dust deposition on the performance of multi-crystalline photovoltaic modules based on experimental measurements, Int. J. Renew. Energy Res. (IJRER) 3, 850-853 (2013)

19. H.A. Kazem, Renewable energy in Oman: status and future prospects, Renew. Sustain. Energy Rev. 15, 3465-3469 (2011)

20. H.A. Kazem, T. Khatib, K. Sopian, W. Elmenreich, Performance and feasibility assessment of a $1.4 \mathrm{~kW}$ roof top grid-connected photovoltaic power system under desertic weather conditions, Energy Build. 82, 123-129 (2014)

21. M.J. Adinoyi, S.A. Said, Effect of dust accumulation on the power outputs of solar photovoltaic modules, Renew. Energy 60, 633-636 (2013)

22. A. Al Shehri, B. Parrott, P. Carrasco, H. Al Saiari, I. Taie, Impact of dust deposition and brush-based dry cleaning on glass transmittance for PV modules applications, Sol. Energy 135, 317-324 (2016)

23. M. Emziane, M. Al Ali, Performance assessment of rooftop PV systems in Abu Dhabi, Energy Build. 108, 101-105 (2015)
24. A.M. El-Nashar, The effect of dust accumulation on the performance of evacuated tube collectors, Sol. Energy 53, 105-115 (1994)

25. M. Hadwan, A. Alkholidi, Solar power energy solutions for Yemeni rural villages and desert communities, Renew. Sustain. Energy Rev. 57, 838-849 (2016)

26. C. Fountoukis, B. Figgis, L. Ackermann, M.A. Ayoub, Effects of atmospheric dust deposition on solar PV energy production in a desert environment, Sol. Energy 164, 94-100 (2018)

27. W. Javed, B. Guo, B. Figgis, Modeling of photovoltaic soiling loss as a function of environmental variables, Sol. Energy 157, 397-407 (2017)

28. B. Figgis, A. Ennaoui, S. Ahzi, Y. Rémond, Review of PV soiling particle mechanics in desert environments, Renew. Sustain. Energy Rev. 76, 872-881 (2017)

29. B. Figgis, A. Nouviaire, Y. Wubulikasimu, W. Javed, B. Guo, A. Ait-Mokhtar et al., Investigation of factors affecting condensation on soiled PV modules, Sol. Energy 159, 488-500 (2018)

30. K. Ilse, M. Werner, V. Naumann, B.W. Figgis, C. Hagendorf, J. Bagdahn, Microstructural analysis of the cementation process during soiling on glass surfaces in arid and semi-arid climates, Phys. Stat. Solidi (RRL)-Rapid Res. Lett. 10, 525-529 (2016)

31. Y. Charabi, A. Gastli, Integration of temperature and dust effects in siting large PV power plant in hot arid area, Renew. Energy 57, 635-644 (2013)

32. T.M. Alnasser, A.M. Mahdy, K.I. Abass, M.T. Chaichan, H.A. Kazem, Impact of dust ingredient on photovoltaic performance: an experimental study, Solar Energy 195, 651-659 (2020)

33. M.T. Chaichan, B.A. Mohammed, H.A. Kazem, Effect of pollution and cleaning on photovoltaic performance based on experimental study, Int. J. Sci. Eng. Res. 6, 594-601 (2015)

34. A. Gholami, I. Khazaee, S. Eslami, M. Zandi, E. Akrami, Experimental investigation of dust deposition effects on photo-voltaic output performance, Solar Energy 159, 346-352 (2018)

35. E. Adıgüzel, E. Özer, A. Akgündogdu, A.E. Yılmaz, Prediction of dust particle size effect on efficiency of photovoltaic modules with ANFIS: an experimental study in Aegean region, Turkey. Solar Energy 177, 690-702 (2019)

36. E. Elshazly, A.A. Abd El-Rehim, A.A. Kader, I. El-Mahallawi, Effect of dust and high temperature on photovoltaics performance in the new capital area, WSEAS Trans. Environ. Dev. 17, 360-370 (2021)

37. R. Majeed, A. Waqas, H. Sami, M. Ali, N. Shahzad, Experimental investigation of soiling losses and a novel cost-effective cleaning system for PV modules, Solar Energy 201, 298-306 (2020)

38. H.A. Kazem, M.T. Chaichan, The effect of dust accumulation and cleaning methods on PV panels' outcomes based on an experimental study of six locations in Northern Oman, Solar Energy 187, 30-38 (2019)

Cite this article as: Hussein A. Kazem, Miqdam T. Chaichan, Ali H.A. Al-Waeli, Kamaruzzaman Sopian, Abdul Salam K. Darwish, Evaluation of Dust Elements on Photovoltaic Module Performance: an Experimental Study, Renew. Energy Environ. Sustain. 6, 30 (2021) 